\title{
Escalating SARS-CoV-2 circulation in environment and tracking waste management in South Asia
}

\author{
Ariful Islam $^{1,2} \cdot$ Md. Abul Kalam ${ }^{3} \cdot$ Md. Abu Sayeed ${ }^{1,4}$. Shahanaj Shano ${ }^{1,4} \cdot$ Md. Kaisar Rahman ${ }^{1,4} \cdot$ Shariful Islam ${ }^{1,4}$. \\ Jinnat Ferdous ${ }^{1,4}$. Shusmita Dutta Choudhury ${ }^{1,4} \cdot$ Mohammad Mahmudul Hassan ${ }^{5}$
}

Received: 1 July 2021 / Accepted: 3 September 2021 / Published online: 23 September 2021

(C) The Author(s), under exclusive licence to Springer-Verlag GmbH Germany, part of Springer Nature 2021

\begin{abstract}
The novel coronavirus disease of 2019 (COVID-19) pandemic has caused an exceptional drift of production, utilization, and disposal of personal protective equipment (PPE) and different microplastic objects for safety against the virus. Hence, we reviewed related literature on severe acute respiratory syndrome coronavirus 2 (SARS-CoV-2) RNA detected from household, biomedical waste, and sewage to identify possible health risks and status of existing laws, regulations, and policies regarding waste disposal in South Asian (SA) countries. The SARS-CoV-2 RNA was detected in sewage and wastewater samples of Nepal, India, Pakistan, and Bangladesh. Besides, this review reiterates the enormous amounts of PPE and other single-use plastic wastes generated from healthcare facilities and households in the SA region with inappropriate disposal, landfilling, and/or incineration techniques wind-up polluting the environment. Consequently, the Delta variant (B.1.617.2) of SARS-CoV-2 has been detected in sewer treatment plant in India. Moreover, the overuse of non-biodegradable plastics during the pandemic is deteriorating plastic pollution condition and causes a substantial health risk to the terrestrial and aquatic ecosystems. We recommend making necessary adjustments, adopting measures and strategies, and enforcement of the existing biomedical waste management and sanitation-related policy in SA countries. We propose to adopt the knowledge gaps to improve COVID-19-associated waste management and legislation to prevent further environmental pollution. Besides, the citizens should follow proper disposal procedures of COVID-19 waste to control the environmental pollution.
\end{abstract}

Keywords COVID-19 $\cdot$ Environment $\cdot$ Waste management $\cdot$ Sanitation $\cdot$ Public health $\cdot$ South Asia

\section{Introduction}

Hospital waste is increasing in volume and variety worldwide (Adu et al. 2020; Harhay et al. 2009) with the expansion of

Responsible Editor: Lotfi Aleya

Ariful Islam

arif@ecohealthalliance.org

1 EcoHealth Alliance, New York, NY 10001-2320, USA

2 Centre for Integrative Ecology, School of Life and Environmental Science, Deakin University, Burwood, Victoria 3216, Australia

3 Helen Keller International, Dhaka 1212, Bangladesh

4 Institute of Epidemiology, Disease Control and Research (IEDCR), Dhaka 1212, Bangladesh

5 Faculty of Veterinary Medicine, Chattogram Veterinary and Animal Sciences University, Chattogram 4225, Bangladesh hospitals and diagnostic laboratories for the extended population where space for waste disposal is decreasing (Ali et al. 2017). There is evidence of infectious diseases spreading like hepatitis, cholera, and typhoid due to improper disposal of single-use biomedical equipment (WHO 2018). The developed countries either dump the waste into sanitary landfill or convert them into energy. However, the developing countries dump their biomedical and municipal solid waste in the poorly managed open areas (Idris et al. 2004) that increases a serious public health concern for the water, sanitation, and hygiene (WASH) sector (Yasmin and Rahman 2017).

Medical waste is a significant concern to human health and to the environment considering the global transmission of severe acute respiratory syndrome coronavirus 2 (SARS-CoV2) (Islam et al. 2021a). Lack of proper hospital waste management might proceed the spread of coronavirus disease of 2019 (COVID-19) to medical staff, patients, and people who are involved with waste management as well as to community people (Rahman et al. 2020b; Xu et al. 2020b). With the 
increase of COVID-19 cases, a concern has raised globally about the contamination risks associated with solid waste from hospital and household, as many COVID-19 diagnosed patients do not need hospitalization and remain in isolation at home.

In terms of disease incidence and case-fatality rates, some developed countries have largely stuck while other countries are experiencing a different type of loss. However, the impact of this pandemic is long-lasting in many developing countries in South Asia (SA) region. As of June 25, 2021, the SA countries have 33,024,044 reported cases with 445,817 deaths (Worldometer 2021). Environmental and clinical data implies that SARS-CoV-2 can spread through environmental routes. For instance, several studies stated the existence of the SARSCoV-2 virus in feces samples of symptomatic and asymptomatic patients (Foladori et al. 2020; Lesimple et al. 2020; Randazzo et al. 2020a; Sunkari et al. 2020; Wong et al. 2020; Xiao et al. 2020). SARS-CoV-2 was detected in the wastage, primary effluents, and even in treated waste-water in different countries (Kumar et al. 2020d). The noninfectiveSARS-CoV-2 RNA fragments have been identified in waste water before clinical cases diagnosed in Milan, Italy (Rimoldi et al. 2020; Murcia, Spain (Randazzo et al. 2020b); Brisbane, Australia (Kitajima et al. 2020); multiple locations in the Netherlands (Medema et al. 2020); New Haven and eastern Massachusetts (Peccia et al. 2020; Wu et al. 2020a), USA; and Paris, France (Wurtzer et al. 2020).

The SARS-CoV-2 survives in the environment for several hours to several days. It can live for a few days on surfaces and plastic that emerge from households; thus, quarantine facilities might act as a source of infection to other individual (Nghiem et al. 2020; Qu et al. 2020). Waste generation due to COVID19 including PPEs and discarded plastics might raise the environmental and human health crisis globally (Singh et al. 2020b). However, waste disposal is a primary interest to many countries amidst the pandemic where waste management is not adequately regulated (Singh et al. 2020a). Among SA countries, the usual scenario is that, the waste pickers collect wastes and dump the waste at areas where animal species like dogs, pigs, goats, and cows roam around frequently (Nzediegwu and Chang 2020). Besides, limited incineration facilities or unsuitable equipment using for incineration can pollute the air and increase the volume of ash residue, which harms human health through carcinogens (WHO 2018). In line with the growing number of COVID-19 cases globally, the situation has been exacerbating due to the increased use of medical equipment, PPE, and testing kits at the hospital settings.

Collection and transportation of unsealed COVID-19 waste over significant distances are perilous. The standard for medical waste dumping is to burn under controlled environments at over $1000^{\circ} \mathrm{C}$, and discharge the smoke into the environment subsequent to separating hurtful particles (WHO 2005b). So, unusual dumping of COVID-19 waste produces much harm to human and environmental health. Therefore, this review article aimed to identify the systems, approaches, and recommendations regarding waste management and identify health and environment risks in SA countries while Bangladesh's situation has been analyzed as a case study.

\section{Methodology}

We conducted the present narrative review by searching all the pertinent literature through Google Scholar, Google search engine, PubMed, and Scopus. We tried to find out the published protocol of COVID-19 and other biomedical waste management by World Health Organization (WHO) and SA countries. We searched for published articles which reported the contamination and impact of biomedical and COVID-19 wastes on the environment of SA countries with attention on Bangladesh. We have searched the databases using Boolean words "AND", and "OR" with [All fields] and [MeSH terms] searching strategies based on our targeted objectives. We developed the Boolean words using a descriptive, outcome, population, and area term.

\begin{tabular}{|c|c|}
\hline Term & Keywords \\
\hline $\begin{array}{l}\text { Descriptive } \\
\text { term }\end{array}$ & $\begin{array}{l}\text { Identification OR Detection OR Investigation OR Manual } \\
\text { OR Management }\end{array}$ \\
\hline $\begin{array}{l}\text { Outcome } \\
\text { term }\end{array}$ & $\begin{array}{l}\text { Waste OR Biological Waste OR Bio-waste OR } \\
\text { Biomedical Waste OR Medical Waste OR Coronavirus } \\
\text { OR SARS-CoV-2 OR COVID-19 }\end{array}$ \\
\hline $\begin{array}{l}\text { Population } \\
\text { term }\end{array}$ & Environment OR Wastewater OR Sewerage \\
\hline Area term & $\begin{array}{l}\text { South Asia OR Bangladesh OR Nepal OR Bhutan OR Sri } \\
\text { Lanka OR Pakistan OR India OR Afghanistan }\end{array}$ \\
\hline
\end{tabular}

\section{Sewage management in developing nations}

The environment can act as a source of infection when it becomes contaminated with infected materials of human origin accumulated through defecation, urination, oral and respiratory secretions, blood, and sweat. Several human pathogens including norovirus, hepatitis A and E virus, different viruses under adenoviridae, astroviridae, enteroviridae, and reoviridae family are documented of being transmitted to the community level through contaminated water (Gerba et al. 2017; LeChevallier et al. 2020; Sinclair et al. 2008). Developed nations have planned adequate arrangements to reduce this kind of environmental transmission, which are effortlessly being implemented because of having adequate resources (Tudor et al. 2005) whereas developing countries need to improve 
their capacity significantly to actualize such kind of arrangements.

\section{Sewage management in SA countries}

Sewage management has become more critical in current years in the urban setting of the SA region. Factors like extended population, economic development, and changing consumption patterns are increasing solid waste generation. However, solid waste is a visible environmental problem in many urban areas of the SA countries (Iliyas 2008; Khan et al. 2012; Shekdar 2009). Disposal of sewage in open spaces, rivers, and canals by households and industries is common in those areas. Besides, proper dumping of sludge and sewage is very infrequent, the constitutive support for sewage management system is limited, and information and implementation are slow and relaxed (Ray 2008).

Table 1 summarizes the sanitation system of SA countries. The existing sewage disposal method in SA countries is increasing the humans' health hazards (Dhokhikah and Trihadiningrum 2012) which is aggravated by unusual collection and lack of treatment of the sewage. Moreover, partly cured or uncured effluents are released into water streams which contaminate the water bodies and pose risk to both environment and public health (Kamal et al. 2008). Among SA countries, the sewage management regulations are made mainly to establish the responsibility and expectation connected with the managing authorities, usually the municipality rather than community people (Shekdar 2009).

\section{Sewage management in Bangladesh}

Bangladesh has been suffering from water-borne diseases for a long time, due to inadequate sewage treatment plants for effluent and solid waste with inappropriate attention and management. The sewages are being discharged into nearby waterbodies ultimately polluting the environment (Hasan et al. 2019). Dhaka, the most densely populated and capital city's sewage and sanitation system are inadequate, covering only $30 \%$ of the total population (Alam et al. 2020). There are 50,000 septic tanks in Dhaka, and 15\% people use buckets and pit latrines where the rest do not have a proper sewage disposal system (Azharul Haq 2006; Sharmin 2016). During the rainy season, sewage overflow into storm drains, and unhygienic conditions aggravate the spread of microorganisms (Azharul Haq 2006). Slum-dwellers of big cities, like Dhaka, live in compact conditions with an unhygienic environment where most of the water supply is unhealthy and contaminated. There are over 1600 slums in Dhaka city with about 500,000 populations; many families in slums share one latrine, and majority percentage of people share only one water source (Mansour et al. 2017). People of slum areas do not practice use of masks, hand washing, and social distancing. This might surge the risk of coronavirus transmission in the slum areas of Bangladesh (Banik et al. 2020) and increase the chance of more infectious waste production (Islam and Kibria 2020). In rural areas, wastes are dumped or burned in an open area as there are no waste collection facility (Boechat et al. 2017). Besides, dustbins are unavailable in the rural community, so that people dump their wastes on the roadside pit or drain, waterbodies, vacant plots near the household (Sheheli 2007).

\section{Wastewater-based surveillance and detection of SARS-CoV-2 in sewer water in SA countries}

Wastewater-based surveillance has long been used to recognize the existence of viruses and different microbes in sewer water. Determinants of antimicrobial resistance, for example, resistance microbes, genes, or antimicrobial residues, have been recognized in sewage or wastewater samples. For instance, poliovirus surveillance in sewage helped to monitor its circulation in the environment (Foladori et al. 2020).
Table 1 The status of sanitation in South Asian countries (WHO 2020)

\begin{tabular}{lllllll}
\hline Country & \multicolumn{2}{l}{ Sanitation status $(\%)$} & & $\begin{array}{l}\text { Sanitation connected } \\
\text { with the septic tank } \\
(\%)\end{array}$ & $\begin{array}{l}\text { Sanitation } \\
\text { connected with } \\
\text { sewer (\%) }\end{array}$ \\
\cline { 2 - 6 } & Basic & Limited & Unimproved & $\begin{array}{l}\text { Open } \\
\text { defecation }\end{array}$ & & \\
\hline Afghanistan & 43.41 & 9.82 & 34.01 & 12 & 9.89 & 2.59 \\
Bangladesh & 48.23 & 22.64 & 29.12 & 0 & 13.47 & 5.24 \\
Bhutan & 69.25 & 9.04 & 21.69 & 0 & 51.36 & 5.62 \\
India & 59.54 & 12.5 & 2.22 & 25 & 33 & 10.56 \\
Sri Lanka & 95.78 & 3.07 & 0.58 & 1 & 1.96 & 4.18 \\
Maldives & 99.37 & 0.62 & 0 & 0 & 35.98 & 60.13 \\
Nepal & 62.05 & 13.68 & 2.76 & 21 & 48.93 & 5.12 \\
Pakistan & 59.86 & 10.18 & 19.51 & 10 & 33.07 & 25.23 \\
\hline
\end{tabular}


Sewage data can be used for surveillance to identify the existence of the virus in a community. Sewage sampling and testing from wastewater treatment plant can help screen the entire city utilizing only small resources.

Current knowledge evokes that the survival of different coronavirus depends on the nature and type of wastewater along with the variation of temperature. Table 2 illustrates the persistence of different coronavirus on different types of liquids and wastewater. Evidence suggests that temperature is one of the major determinants of virus survival in the environment. The SARS-CoV-2 persisted for 35 days at a lesser temperature of $4^{\circ} \mathrm{C}$, while, at the higher temperature of $25^{\circ} \mathrm{C}$, they live on for 21 days. However, the current evidence also suggests that persistence also varied based on the type of virus. Casanova et al. (2009) found that porcine transmissible gastroenteritis virus (TGEV) exists for 35 days on pasteurized settled sewage at $4^{\circ} \mathrm{C}$ temperature while its persistence decreased to 21 days while temperature increases to $25^{\circ} \mathrm{C}$. In case of SARS-CoV-1, the persistence depends on the temperature of domestic sewage (Wang et al. 2005). Human coronavirus, $\mathrm{HCoV}-229 \mathrm{E}$ persisted in the primary and secondary effluent for 2 days at $23^{\circ} \mathrm{C}$ (Gundy et al. 2009). Thus, SARS-CoV-2 can spread via gasp of filthy aerosols and droplets from effluent particularly in the residential areas with heavy population density, which has been identified as hotspots of COVID-19(Islam et al. 2021b; Islam et al. 2020)(Table 2).

Moreover, about $80 \%$ of COVID-19 patients remain in their house expecting to be recovered without getting hospital treatment (Quilliam et al. 2020; Rahman et al. 2020a) and might increase the contamination of sewage water through feces, and respiratory excretion (Kam et al. 2020; Kataki et al. 2020). The Ribonucleic acid (RNA) of SARS-CoV-2 immediately becomes disintegrated in sewage water and may be steady whenever secured by the protein coat, capsid. Therefore, fragments of RNA in sewage is the evidence of the probable circulation of SARS-CoV-2 in waste (Kitajima et al. 2020; Mandal et al. 2020). However, after the emergence of the current pandemic, around 30 studies have reported evidence of SARS-CoV-2 in wastewater (Ahmed et al., 2020;

Table 2 Persistence of coronaviruses suspended in different medium and surfaces

\begin{tabular}{|c|c|c|c|c|}
\hline Type of virus & Surface/media & Temp ( $\left.{ }^{\circ} \mathrm{C}\right)$ & Persistence & Reference \\
\hline \multirow[t]{4}{*}{ SARS-CoV-2 } & Plastic & 22 & $4 d$ & \multirow[t]{3}{*}{ Chin et al. 2020} \\
\hline & Glass & 22 & $2 \mathrm{~d}$ & \\
\hline & Cloth & 22 & $1 \mathrm{~d}$ & \\
\hline & Stainless steel & 22 & $4 d$ & van Doremalen et al. 2020 \\
\hline \multirow[t]{9}{*}{ SARS-CoV-1 } & Domestic sewage, hospital wastewater, dechlorinated tap water & 20 & $2 \mathrm{~d}$ & \multirow[t]{6}{*}{ Wang et al. 2005} \\
\hline & & 4 & $>14$ & \\
\hline & Stool & 20 & $3 \mathrm{~d}$ & \\
\hline & Stool & 4 & $>17 \mathrm{~d}$ & \\
\hline & Urine & 20 & $17 \mathrm{~d}$ & \\
\hline & Urine & 4 & $>17 \mathrm{~d}$ & \\
\hline & Plastic & $21-25$ & $6 \mathrm{~d}$ & Rabenau et al. 2005 \\
\hline & Glass & $21-25$ & $4 d$ & \multirow[t]{2}{*}{ Duan et al. 2003} \\
\hline & Cloth & $21-25$ & $5 \mathrm{~d}$ & \\
\hline \multirow{2}{*}{ MERS-CoV } & Plastic & 30 & $8 \mathrm{~h}$ & \multirow[t]{2}{*}{ van Doremalen et al. 2020} \\
\hline & Stainless steel & 20 & $2 \mathrm{~d}$ & \\
\hline $\mathrm{HCoV}$ & Wastewater & 23 & $<4 d$ & \multirow[t]{5}{*}{ Gundy et al. 2009} \\
\hline \multirow[t]{2}{*}{ Poliovirus-1 } & Primary wastewater & 23 & $11 \mathrm{~d}$ & \\
\hline & Secondary effluents & 23 & $6 \mathrm{~d}$ & \\
\hline FIPV & Primary effluent & 23 & $1 \mathrm{~d}$ & \\
\hline \multirow[t]{4}{*}{ HCoV-229E } & Primary effluent & 23 & $2 \mathrm{~d}$ & \\
\hline & Plastic & $21-25$ & $2 \mathrm{~d}$ & Rabenau et al. 2005 \\
\hline & Aluminum & 21 & $6 \mathrm{~h}$ & Sizun et al. 2000 \\
\hline & Stainless steel, Glass & 21 & $5 \mathrm{~d}$ & Warnes et al. 2015 \\
\hline HCoV-OC43 & Aluminum & 21 & $2 \mathrm{~h}$ & Sizun et al. 2000 \\
\hline MHV & Unpasteurized wastewater & 25 & $3.25 \mathrm{~h}$ & Ye et al., 2016 \\
\hline
\end{tabular}

SARS-CoV, Severe Acute Respiratory Syndrome Coronavirus; $M E R S$, Middle East Respiratory Syndrome; $H C o V$, Human Coronavirus; FIPV, Feline Infectious Peritonitis Virus; $M H V$, Murine Hepatitis Virus 
Ahmed et al., 2021; Albastaki et al. 2020; Arora et al. 2020b; Haramoto et al. 2020; Kumar et al., 2020b; Sharif et al. 2020; Xu et al. 2020; Yaqub et al. 2020; Zhang et al. 2020).

Using real-time reverse transcriptase polymerase chain reaction (rRT-PCR) assay, several researchers identified SARSCoV-2 RNA in the stool in different regions (Ghinai et al. 2020; Lo et al. 2020; Wölfel et al. 2020). Although the current knowledge on the existence of SARS-CoV-2 in the stool generated based on the small number of samples, hence there is a critical need to assess the potentiality of transmission of the virus through fecal contamination with a larger sample size. However, the present review indicates the release of SARS$\mathrm{CoV}-2$ into effluent and onsite sanitation systems, and even via open defecation (Gwenzi 2020). Although there is lack of epidemiological evidence, however, the recent trend of the multifaceted route of SARS-CoV-2 infections indicated orofecal transmission (Ahmed et al., 2020; Goh et al. 2020; Wu et al. 2020b).

Among SA countries, Nepal detected the presence of SARS-CoV-2 RNA in sewage sample (Napit et al. 2021). India detected the SARS-CoV-2 RNA from waste water treatment plant sampled between 8 and 27 May, 2020 (Kumar et al., 2020c). Amin et al. (2019) conducted a study including 6 hospitals and found that none of them has wastewater treatment facility; only 3 of them had anaerobic baffled reactor for waste containment and the rest 3 directly dispose wastewater to the environment. The study also found $67 \%$ wastewater samples from those hospitals contained SARS-CoV-2 RNA (Amin et al. 2021). Another study from Bangladesh detected SARS-CoV-2 genetic material from wastewater near a COVID-19 isolation center in Noakhali district (Ahmed et al. 2021). Though SARS-CoV-2 RNA can be found in untreated waste water, but it was absent in secondary and tertiary treated effluent (Arora et al. 2020a). Table 3 summarizes the current literature on the presence of SARS-CoV-2 in untreated effluent, raw sewage, septic tank effluent, river water, and hospital septic tank. These evidence suggest that untreated wastewater, raw sewage, and river water could be crucial mode of environmental spread of SARS-CoV-2(Table 3). Fecal wastes are released in drains, rivers, and canals without any treatment in Dhaka, Bangladesh. SARS-CoV-2 RNA was found in $35-40 \%$ of wastewater samples from Dhaka (Haque et al. 2020).

The SA countries are in highly vulnerable position in regard to SARS-CoV-2 spread through untreated wastewater, feces, and sewage as a result of poor hygiene and sanitation. Over 600 million people practice open defecation, and 134 million people do not get proper sanitation facility (Unicef 2020). The poor hygiene, sanitation, disinfection practices in healthcare facilities, and households without proper disposal and treatment of wastewater exposing the people of SA countries to SARS-CoV-2 in the environment (Pandey et al. 2020). In Bangladesh, India, Nepal, and Pakistan, $65.0 \%$ of urban residents, or 368 million people, have access to an improved latrine $(14.0 \%)$, septic tank (44.0\%), or sewer connected system $(42.0 \%)$ (WaterAid 2019 ) whereas only $9.3 \%$ of sewerage is treated in these four highly dense populated countries (WHO 2020). Again, around $20 \%$ of the city people in Bhutan has central sewer system facilities (Dorji et al. 2019). The situation is almost similar in other countries (Table 3).

\section{Biomedical wastage management amid the COVID-19 pandemic}

About $75-90 \%$ biomedical wastes are harmless, while the residuals are considered as unsafe (Chartier 2014). Common medical waste items include infected blood sample, intravenous (IV) suppository equipment, anatomy, and pathological wastes (WHO 2005a). These wastes might be a source of evolving pollutants engendered by health care appliance used for medical diagnosis, treatment, and immunization for diseases (Datta et al. 2018).

\section{Biomedical waste management in SA countries}

Managing medical waste is a challenge for many states worldwide. The medical waste production has been increased notably due to growth of population and health care facilities (Mohee 2005). It is estimated that around 10-25\% of medical waste is infectious and hence hazardous (Chartier 2014). By contrast to developing countries, developed countries are generating more wastes due to commonly use of disposable equipment (Abd El-Salam2010). Safe and sustainable biomedical waste management is not regulated in developing countries (Singh et al. 2020a; Singh et al. 2020b). Because of the poor waste management system in developing countries, biomedical waste may mix up with non-perilous kitchen waste (Thakur and Ramesh 2015). Sometimes, perilous biomedical wastes, mixed with city waste, are inflamed under the open sky. These wastes are sometimes treated inappropriately and often reused increasing the danger for both human health and environment (Kerdsuwan and Laohalidanond 2015; Mahmood et al. 2011; Mohankumar and Kottaiveeran 2011). Thus, a proper biomedical waste management and disposal system are essential as it can affect the public health and environmental health (Abdulla et al. 2008; Ali et al. 2016).

Different biomedical wastes like gauze, bandage, disposable syringe, needles, gloves, face masks and other PPE materials contaminated by fomites, blood, fluids; laboratory wastes contaminated by cultures; and hospital wards' waste are increasing day by day (Zamparas et al., 2019). Millions of people are using protective gears e.g; facial masks and other respiratory protective kit across the globe to minimize the risk of SARS-CoV-2. As a result, millions of tons of biomedical waste are producing every day (Anon 2011). Using 
Table 3 Reported molecular detection of SARS-CoV-2 in the wastewater of South Asian countries

\begin{tabular}{|c|c|c|c|c|c|c|c|}
\hline Sample type & Country & Location & Detection time & $\begin{array}{l}\text { Detection } \\
\text { methods }\end{array}$ & PCR target regions & Positive rate & Reference \\
\hline $\begin{array}{l}\text { Untreated } \\
\text { wastewater }\end{array}$ & Bangladesh & Noakhali & $29 / 08 / 2020$ & RT-PCR & ORF1 gene & $12 / 16(75 \%)$ & $\begin{array}{l}\text { Ahmed et al., } \\
2020\end{array}$ \\
\hline $\begin{array}{l}\text { Untreated } \\
\text { wastewater }\end{array}$ & India & Ahmedabad & $27 / 05 / 2020$ & qRT-PCR & ORF-1 gene & $100 \%$ & $\begin{array}{l}\text { Kumar et al. } \\
\text { 2020a) }\end{array}$ \\
\hline Wastewater & India & Jaipur & $\begin{array}{r}04 / 05 / 2020 \text { to } \\
12 / 06 / 2020\end{array}$ & RT-PCR & $\begin{array}{l}\text { S gene, E gene, ORF1 } \\
\text { gene, RdRp gene and N } \\
\text { gene }\end{array}$ & $6 / 17(35 \%)$ & $\begin{array}{l}\text { Arora et al. } \\
2020 \mathrm{~b}\end{array}$ \\
\hline $\begin{array}{l}\text { Sewage Treatment } \\
\text { Plant }\end{array}$ & India & Vinzol-Ahmedabad & $\begin{array}{l}26 / 11 / 2020 \\
\text { and } 08 / 02 / 2021\end{array}$ & RT-PCR & $\mathrm{S}$ gene & Not known & GISAID 2021 \\
\hline Sewage & India & Hyderabad & $\begin{array}{r}8 / 7 / 2020 \text { to } \\
6 / 8 / 2020\end{array}$ & RT-PCR & E, N \& ORF1ab gene & $100 \%$ & $\begin{array}{l}\text { Hemalatha } \\
\text { et al. } 2021\end{array}$ \\
\hline $\begin{array}{l}\text { Sewage samples and } \\
\text { hospital } \\
\text { wastewater }\end{array}$ & India & Chennai & $\begin{array}{l}5 / 9 / 2020 \text { to } \\
11 / 9 / 2020\end{array}$ & qRT-PCR & $\mathrm{N} 1, \mathrm{~N} 2$ gene & $100 \%$ & $\begin{array}{l}\text { Chakraborty } \\
\text { et al. } 2021\end{array}$ \\
\hline Sewage & Pakistan & Lahore & $\begin{array}{r}13 / 7 / 2020 \text { to } \\
25 / 7 / 2020\end{array}$ & qRT-PCR & ORF1ab, N gene & $16 / 28(54.1 \%)$ & $\begin{array}{l}\text { Yaqub et al. } \\
2020\end{array}$ \\
\hline $\begin{array}{l}\text { Untreated } \\
\text { wastewater }\end{array}$ & Pakistan & Multiple locations & $\begin{array}{r}20 / 03 / 2020 \text { to } \\
09 / 04 / 2020\end{array}$ & RT-PCR & $\mathrm{N}$ gene & $21 / 78(27 \%)$ & $\begin{array}{l}\text { Sharif et al. } \\
2020\end{array}$ \\
\hline Sewage & Nepal & Multiple locations & $\begin{array}{r}13 / 05 / 2020 \text { to } \\
05 / 07 / 2020\end{array}$ & RT-PCR & $\begin{array}{l}\text { E gene, RdRp gene, and } \mathrm{N} \\
\text { gene }\end{array}$ & $16 / 20(80 \%)$ & $\begin{array}{l}\text { Napit et al. } \\
2021\end{array}$ \\
\hline
\end{tabular}

mathematical models, a recent study showed that SA nations including Afghanistan, Bangladesh, Bhutan, India, Maldives, Nepal, Pakistan, and Sri Lanka produce 8766.36 t of infected biomedical waste daily (Sangkham 2020). Moreover, the comparative analysis showed the highest medical wastes are generated in India (6491.49, t/day), trailed by Pakistan (1999.30 t/day), and Bangladesh (927.81 t/day) (Table 4). Over the time, the amount of medical waste is increasing with the expansion of confirmed cases and extended use of protective gears, highly recommended for infected persons, their family members, and health care workers. These wastes are creating environmental and community health crises worldwide. Infected waste also comes from the household as many COVID-19 diagnosed patients remain at home in isolation (Penteado and de Castro 2020). All sorts of protective kits are disposing along with the household trash could increase the risk of coronavirus transmission in communities.

Unfortunately, the SA countries have limitations to manage health care wastes $(\mathrm{HCW})($ Ananth et al. 2010) and lack of safe waste disposal (Sangkham 2020). The common problem is disposal methods including lack of collection coverage (Sembiring and Nitivattananon 2010). In highly dense SA countries like Bangladesh, Bhutan, India, Nepal, Pakistan, and Sri Lanka, the management of wastes is mostly done by the informal private sector, waste pickers, and middlemen (Amin 2020). Disposal of COVID-19 waste mixed with other infected biomedical waste leads to contaminate general solid waste and increases the risk of pathogen transmission (Ilyas et al. 2020; Sharma et al. 2021)(Table 4). Dumping and
Table 4 Use of face mask and production of medical waste in South Asian countries (Sangkham 2020)

\begin{tabular}{lll}
\hline Country & Use of face mask per day (pieces) & Production of medical waste per day (tons) \\
\hline Afghanistan & $19,589,901$ & 144.34 \\
Bangladesh & $99,155,739$ & 927.81 \\
Bhutan & 278,639 & 0.40 \\
India & $381,179,657$ & 6491.49 \\
Maldives & 148,090 & 14.69 \\
Nepal & $19,046,387$ & 77.21 \\
Pakistan & $61,762,860$ & 1099.30 \\
Sri Lanka & $17,136,519$ & 11.12 \\
\hline
\end{tabular}


throwing infectious waste randomly can pose a threat to the waste management workers (Sharma et al. 2020).

The condition of a country's economy reflects on waste elements, as high-income bunches utilize excessive amount of wrapped items, bringing about larger quantity of plastics, glassware, and weaves (Ragaert et al. 2004). Changes in the waste ingredients can fundamentally affect waste managing rehearses (Abdel-Shafy and Mansour 2018). Municipal solid waste may have risky components, for example, discarded batteries, insecticides, tints, left over, and expired drug where degradable organics incorporate natural products, vegetables, and food wastes. As per India's Central Government Act on Biomedical Waste (management and handling) Rules 1998 and the Amended Rules, 2003, biomedical wastes which include dispensable needles and hygienic objects stained with blood ought not be blended with solid wastage (Kumar et al. 2017). Most decomposable waste is produced from homestead where inert waste is produced from the manufacturing, destruction, and street cleaning. A comparable report likewise found that waste examples gathered from Delhi, Ahmedabad, and Bangalore show that the urban solid wastage elements fluctuate between municipal communities (Kumar et al. 2020a).

Effective medical waste management includes proper classification, gathering, storing, carriage, disinfection, and dumping which minimize the possibilities of virus transmission (Sharma et al. 2020). All the SA countries have specific rules, acts, or guidelines for managing medical waste (Table 5). Joint Monitoring Program on WASH shows that proper biomedical waste management is poor despite having relevant rules or acts in the SA countries. Indecorous treatment of biomedical waste could exacerbate the transmission of coronavirus in the SA countries (Saadat et al. 2020). When the government enforces mandatory face mask use policies in public areas to protect themselves from COVID-19, mask supplies were scarce around the world (Feng et al. 2020). Several syndicates then resold discarded products resulting in indirect exposure of the people to SARS-CoV-2(Haque et al. 2020). The aggregation of single-use medical substances and selling for re-use without purification might produce a worrying disease concern (Table 5).

\section{Biomedical waste management in Bangladesh}

Despite having a legislative framework on biomedical waste management in Bangladesh, disposing of $\mathrm{HCW}$ is practicing inappropriately and haphazardly (Behnam et al. 2020). The situation is even worse in the major cities, where medical waste is disposed of in open areas such as wastebins, open lands, roadsides, drains, and rivers. Around 59\% of the hospitals dispose their wastes in city corporation's bins without separation (Nasrin 2016). Studying environmental and occupational health hazards in Chattogram, Bangladesh reported inadequacy in the acquaintance of hospital waste management even among heath care workers (Behnam et al. 2020). Unskilled waste pickers handle medical waste which ultimately puts them at high risk of contracting infectious diseases (Saadat et al. 2020).

The condition has been exacerbating during this pandemic. As of 8 August 2020, the Directorate General of Health Services (DGHS) of Bangladesh has provided 76,653 pieces of apron and gown; 1,123,457 pieces of examination and surgical gloves; $1,201,127$ pieces of shields; $6,787,300$ pieces of masks; 1,104,674 pieces of PPE kits; and 189,232 pieces of sanitizers to different hospitals (Shammi and Tareq 2020). The ultimate destination of these supplies will be wastebin. In the first month of lockdown (26 Mar-2 Apr 2020) in Dhaka city, nearly $14,500 \mathrm{t}$ of plastic waste materials were produced from single used plastic items and PPEs with an average of $483 \mathrm{t}$ per day (ESDO 2020). The estimation also showed that the use of polythene-made shopping bags has been also increased about $5796 \mathrm{t}$ (193.20 $\mathrm{t}$ per day) during the same period. In the capital city, Dhaka, waste produced from solid usable plastic (SUP) items were about $3076 \mathrm{t}$ alone. Moreover, the estimated surge of polythene made hand gloves were

Table 5 Waste management and environmental cleaning in health facilities in South Asian countries (WHO 2020)

\begin{tabular}{|c|c|c|c|c|c|c|c|c|c|}
\hline \multirow[t]{2}{*}{ Countries } & \multicolumn{5}{|c|}{ Waste Management } & \multicolumn{3}{|c|}{ Environmental cleaning } & \multirow{2}{*}{$\begin{array}{l}\text { Active rule or act } \\
\text { or guidelines }\end{array}$} \\
\hline & $\begin{array}{l}\text { Basic } \\
(\%)\end{array}$ & $\begin{array}{l}\text { Limited } \\
(\%)\end{array}$ & $\begin{array}{l}\text { No management } \\
(\%)\end{array}$ & $\begin{array}{l}\text { Waste segregated } \\
(\%)\end{array}$ & $\begin{array}{l}\text { Waste treated } \\
(\%)\end{array}$ & $\begin{array}{l}\text { Basic } \\
(\%)\end{array}$ & $\begin{array}{l}\text { Limited } \\
(\%)\end{array}$ & $\begin{array}{l}\text { No cleaning } \\
(\%)\end{array}$ & \\
\hline Afghanistan & - & - & - & - & - & - & - & - & Yes \\
\hline Bangladesh & 16 & 71 & 13 & 34 & 29 & - & - & - & Yes \\
\hline Bhutan & 36 & - & - & 80 & 50 & 5 & 55 & 40 & Yes \\
\hline India & - & - & - & - & - & - & - & - & Yes \\
\hline Maldives & 30 & - & - & 47 & 59 & 18 & 38 & 44 & Yes \\
\hline Nepal & 1 & 62 & 36 & 5 & 21 & - & - & - & Yes \\
\hline Pakistan & 49 & - & - & 84 & 51 & - & - & - & Yes \\
\hline Sri Lanka & 27 & 69 & 4 & 51 & 44 & - & - & - & Yes \\
\hline
\end{tabular}


$101.30 \mathrm{t}$ per day where the used bottles of sanitizers and disinfectants were $30 \mathrm{t}$ per day (Faisal et al. 2021). Collection, washing, and re-marketing of used masks, PPE, hand gloves, and empty plastic bottles from various hospitals and dumping yard were usual during the pre-pandemic time (Hassan et al. 2008; Syed et al. 2012). However, to cope with the increased demand for masks, gloves, and PPEs in the absence of regulatory monitoring, the gangs' re-cycling and re-selling of such hazardous materials have been increased (Haque et al. 2020; Rahman et al. 2020b). Besides, the washing of masks and gloves might increase the water contamination possibility with the risk of waterborne transmission of COVID-19. Therefore, hospital and municipal wastewater might be a possible source of water-based transmission.

WHO and the Environmental Protection Agency (EPA) always urge for proper disposal of hospital waste, as they are infectious and hazardous to the environment (Dana 2011). In Bangladesh, mismanagement of household and HCW has become an important issue for urban inhabitants and large cities due to the unavailability of specific disposal pit or treatment plant (Hasan and Iqbal 2016). Although city corporations/municipalities/urban centers are responsible for solid waste management but most often the waste collection is irregular, leads to unhygienic conditions near the primary collection points (Bahauddin and Uddin 2012). Besides, HCW is also handled by local government, municipalities, vendors, and non-governmental organizations who do not have the proper skill and expertise to comply with proper environmentally safe, and health risk-mitigating disposal mechanisms (Haque et al. 2020; Rahman et al. 2020b). As a result, like many other household wastes, the biomedical hazardous waste is also recycled most often. The scenario became worse when slum people collected the used PPE from hospitals' disposal pits and recycled to earn their livelihood by selling them as there is a high demand and crisis of gloves and masks amid COVID-19 pandemic in Bangladesh (Haque et al. 2020).

The Medical Waste (management and processing) Rules 2008 of Bangladesh does not support mixing up the medical waste with other wastes at any stage of the waste management cycle from discarding from the hospital to the collection, transportation, and further processing (MOHFW 2008). Many infectious viruses, including hepatitis $\mathrm{B}$ and $\mathrm{C}$, human immunodeficiency viruses (HIV), can be transmitted through biomedical wastes and infect others (Faisal et al. 2021). The COVID-19 waste generated from household and healthcare facilities is not properly disposed as per the WHO guidelines in Bangladesh. Therefore, inappropriate disposal of used PPE (including masks, gloves, goggles, and gowns) will create a biohazard and with a negative impact on the environment. In Bangladesh, only one non-government organization is working in Dhaka city to collect the wastes from the hospitals and designated COVID-19 treatment centers using open drums and vans and dispose in Matuail Landfill plant (Rahman et al. $2020 \mathrm{~b}$ ). Though the facility is not modern, it is the only option for COVID-19 medical waste management of Dhaka city where other cities are not having such a minimum setup yet (Faisal et al. 2021).

\section{Health risk through improper biomedical waste management in developing countries}

\section{Health risk through biomedical waste: South Asian perspective}

SARS-CoV-2 can survive in plastic surface more than 7 days and can successfully transmit the infection to the contacted person (Chin and Poon, 2020). More precisely, people can get infection from surface contact and these inanimate objects and spread the infection to others. Infected people with less acute symptoms quarantine themselves at home creating an extreme chance of infection transmission to the persons involved with the disposal of waste materials like masks and gloves. Globally, around 5.2 million people, including 4 million children die every year due to biomedical waste-borne diseases (Faisal et al. 2021). In addition, WHO reported around $25.0 \%$ diseases are due to improper management of biomedical waste (Trivedi et al. 2020). A study conducted in Morocco, found $87 \%$ of the respondents dispose of PPE materials mixed with the household waste in the same garbage basket, and $9 \%$ of the participants discard their wastage in public spaces like roads, drains, and lawns (Ouhsine et al. 2020). Developing countries are not fully implementing medical waste according to their existing healthcare laws and regulations (Rahman et al. 2020b). Thus, it was thought that infection by SARS-CoV-2 might escalate among healthcare givers (Yu et al. 2020). To predict waste production situation in the world during COVID-19, the situation in China, Indonesia, and India might be a suitable example. Hubei Province, China, where the first COVID-19 case was detected, was producing $600 \%$ more biomedical waste than earlier (reached $240 \mathrm{t}$ from $40 \mathrm{t}$ per day) (ADB 2020). The medical waste was increased 40 times in Gurugram city, India within the first 60 days of lockdown (Somani et al. 2020) whereas in the capital of Indonesia, the biomedical waste reached 12,740 $\mathrm{t}$ within 60 days of the first COVID-19 case declaration (Kojima et al. 2020).

In SA countries, the unsustainable practices of solid waste management lead to environmental contamination and increase disease risk. Unplanned disposal in open space and burning waste in open sites near water bodies are hazardous 
for both environmental and human health (Abd Manaf et al. 2009; Ferronato and Torretta 2019). Inappropriate dumping of COVID-19 medical wastes results in mixing with the environment through water, food, soil, air, and livestock and putting the environment and the lives of cross-sections of people in vulnerability. According to WHO guidelines, PPE is considered as hazardous waste once we use it. Besides PPE, various dangerous wastes such as toiletries, bandages, face masks, used oxygen cylinder masks, tubes of biological specimens, saline bags, and single-use sharpies are also being produced in hospitals. If the medical wastes are not appropriately treated, then the infectious agents might be entered into the food cycle through soil and water which could lead to catastrophes. Because of the conditions, introducing microwave technology at various COVID-19 designated hospitals for modern medical waste management would be appropriate.

The modern microwave technology effectively treats many infectious medical wastes (Ilyas et al. 2020). Government and private hospitals can treat medical wastes by setting up individual or more integrated plants. COVID-19 waste is treated as contagious medical waste. So, poor disposal of waste will pose public health threat as well as an environmental threat and might lengthen the outbreak (Rahman et al. 2020b). Single-use plastic including unrecyclable PPE, mask, gloves, and wipes discarded in the environment, might go to the sewer system and clog the sewage channels and worsen environmental pollution (Aragaw 2020; CNN 2020; Rume and Islam 2020). It has dire consequences on human life and the environment (Cheval et al. 2020). Alternatively, the lockdown measures had driven to positive effects on the environment; carbon emission has drastically fallen; air and water pollution eased; and on the other side, negative impact is acoustic hazards increased due to waste disposal, resulting in biomedical activities (Cheval et al. 2020). Current evidence proposes that the COVID-19 virus remains active based on the category of waste and the ambient temperature (Table 2).

\section{Health risk through biomedical waste: Bangladesh perspective}

The socioeconomic situation in Bangladesh is not robust in comparison to many countries, struggling with the COVID-19 pandemic. COVID-19 is generating a large quantity of biomedical waste, such as PPE, facial tissue, oxygen mask, gloves, face shield, safety glasses, gauze pieces, saline bags, disposable syringes, and needles (Rahman et al. 2020b; Shammi and Tareq 2020). Almost 96.7\% participants are aware about the danger of COVID-19, and $98.7 \%$ wear face mask in public places in Bangladesh (Ferdous et al. 2020). Another study reported that almost $94.5 \%$ and $54.8 \%$ people use facemask and hand gloves, respectively though more than $50 \%$ of them was found to dispose used PPEs with household wastes (Islam et al. 2021c). The plastics used in medical products in Bangladesh are non-biodegradable. This microplastics become fragmented after releasing into the environment, and some find their way into the air, water, and soil (Rume and Islam, 2020). Plastics could stay in the environment for a century or more, and thus they enter into our food chain (Thompson et al. 2009). COVID-19 has exposed the fragility of our healthcare structure and raised concerns over our unplanned waste disposal system (Faisal et al. 2021).

Bangladesh has always been notorious for hospital waste management. Around 40,000 informal workers handle the waste in Bangladesh, a majority numbers of which are women and children (over 6000) who worked as waste cleaners in Dhaka. Due to fear of COVID-19, waste handlers reduced by $50 \%$, resulting in more workload among the remaining workers (Haque et al. 2021a, 2021b). By May 18, 2020, around 1500 waste workers have become sick during this pandemic in Bangladesh (Jui 2020). Though the government has approved the Biomedical Waste Management and Processing Acts 2008, none of the health care institutes properly follow the guidelines. As a result, they are gathering the waste materials by untrained, unprotected, and unaware cleaners without categorizing the wastes based on their infectiousness. Generally, city corporations, third-party organizations, and nongovernment organizations collect the waste materials from different hospitals and pile up them in open areas without proper treatment (Rahman et al. 2020a, 2020b). During the pandemic situation, it has further been aggravated. Usually, $0.94 \mathrm{~kg}$ of medical waste is produced each day from each hospital bed and it is assumed that during COVID-19 it has doubled than earlier (Shammi et al. 2020). In Bangladesh, more than $50 \%$ of the people keep their protective materials with regular home-based waste in the single silo.

After using, PPE should be discarded with the standard procedure by the sealed box or biohazard bags in the hospital. Unfortunately, in many hospitals of rural and semi-urban areas, proper waste disposal facilities are absent. Many hospitals are dumping their waste in the backyard or mix them with regular city corporation waste (Shammi and Tareq 2020). In Bangladesh, waste collector's health and safety issues are completely ignored. Furthermore, improper medical waste disposal in the environment can create a risk biodiversity of the acoustic of Bangladesh (Rahman et al. 2020b).Besides SARS-CoV-2 infection, improperly managed drainage networks become successful breeding sites for mosquitoes and flies that influence the vector-borne diseases occurrence, dengue, chikungunya for instances (Gupta et al. 2019). At the initial phase of the pandemic in Bangladesh, there were more cases of dengue than in 2019. Moreover, there are similar symptoms of dengue and SARS-CoV-2 that may also create difficulties in differential diagnosis clinically without laboratory confirmation (Tajmim 2020). 


\section{Status of laws, regulations, and policies regarding biomedical waste disposal during COVID-19 pandemic}

The existing rules for waste management in Bangladesh refers to use of different bins with color-coding like black for harmless, red for high-pitched, and yellow for hazardous wastes (Babu et al. 2009). The bins should be placed on the grounds. Roofed vehicles should be used for transportation of these wastes to the treatment sites every day (IGES 2020). With the technical guidance of the DGHS, local governments should play key role for the treatment of infectious medical waste in Bangladesh. Finally, the local government requires skilled workforce and adequate numbers of modern treatment plant for waste management effectively and efficiently. According to IGES (2020), COVID-19 waste generated from healthcare facilities should be incinerated. But only 5 incinerators have been installed in Bangladesh, among which 3 are active now. The number of incinerators is very negligible compared to the huge amount of biomedical waste. Besides, there are still no strict rules about household COVID-19 waste management in Bangladesh. Therefore, additional strategies are required on how to dispose and treat the HCW (like masks, tissues, and disposable clothes) generated from mainly non-healthcare set-up like households and other public places. As the designated authorities for the proper waste management, the city corporation and municipalities should establish a robust institutional arrangement for collection and management of COVID-19 infectious wastage gathered from both healthcare facilities, household, and public places. We recommend the sterilization of medical waste through autoclaving or UV-rays before transferring to a sanctioned landfill, on-site incineration, or at a distant dedicated compartment. Besides, the mobile ignition or sterilizer unit may indorse the current biomedical waste management framework; as an impermanent measure, secured transferring and disposal facilities are expected for the crisis situation.

Around 120,000 poor workers are involved with the waste management activities, of which over $80 \%$ are children who do not have the knowledge on the environment and its risks. Some chemicals from hospital waste may produce cancer, liver damage, kidney failure, tumors, impotence, behavioral change, and eccentricity among humans. However, medical toxic chemicals have long-term and short-term effects, not only on the workers themselves in the factory but also on the surrounding people. People inhale the invisible dust of plastic objects, which is more dangerous than visible toxic substances. Although, the city corporation and municipalities are the principal stakeholders for safe waste management, people's consciousness is necessary to maintain a healthy atmosphere.

Nevertheless, face masks and other PPEs items are used by the people in their everyday life to prevent infection since the COVID-19 pandemic began but major concern raised about their safe discarding and disposal. Most of the SA nations have taken few measures that are aggregated in Table 6.

We recommend the following steps to safe disposal of masks and other single used plastic items during the COVID-19 pandemic in different settings-

Coronavirus isolation wards and testing laboratories: Used masks (counting triple-layer mask, N95 mask etc.) must be disposed of and gathered in discrete "yellow-shading coded plastic packs" (appropriate for biomedical waste assortment). They must be given over to the waste management authority connected with a typical biomedical waste treatment facility administrator at the doorstep and ought to be sterilized.

Interim isolation centers and residence: The used mask ought to be kept in a paper sack for at least $72 \mathrm{~h}$ before their removal as broad waste. We should do this under the Solid Waste Management Rules, 2016. We additionally encourage it to slice the covers before removal to forestall their reuse.

By the end of the year 2020, the public health specialists warned about the possible second wave of SARS-CoV-2(Xu and Li 2020). Currently, many South Asian countries like India, Pakistan, Srilanka, and Bangladesh are experiencing the second wave, and other countries like South Africa are experiencing the third wave of COVID-19(Amin et al. 2021). India started experiencing the havoc of mutant variant of concern (VOC) of SARS-CoV-2 (Delta variant) since September (GISAID 2021). Till June 2021, four viruses (EPI-ISL-2484895, EPI-ISL-2484897, EPI-ISL-2484898, EPI-ISL-2484899) of the highly contagious Delta variants (lineage B.1.617.2) have detected from sewer treatment plant in India having complete alikeness with circulating virus (GISAID 2021). Bangladesh is also experiencing the second wave followed by third wave due to exposure and transmission of VOC-Beta (B.1.351.3) and Delta (B.1.617.2) (GISAID 2021). Hence, it is important to apply deactivation methods to control and contain the potential spread of COVID-19 through different means of environmental routes including biomedical waste and wastewater. Besides, the trend shows the close relationship between temperature and the number of cases (Hassan et al. 2020; Islam et al. 2020). The surge of COVID-19 infection was found to be very high among the countries of cold dominant weather. Considering these issues, we ought to encourage non-quarantined homes and occupants to discard utilized masks by sterilizing them with conventional bleach solution (5\%) or sodium hypochlorite solution (1\%). Furthermore, wrap and keep in a shut container prior to giving the mask over to the sanitary worker. This waste ought to be treated as homegrown hazardous waste and burned by the city corporation. Though the incineration 
Table 6 Current practices of management, treatment, and disposal at health care facilities and relevant guidelines on COVID-19 induced waste in selected South Asian countries

\begin{tabular}{|c|c|c|c|c|}
\hline Country & WHO standard & $\begin{array}{l}\text { Management of COVID-19 in- } \\
\text { duced waste in healthcare ame- } \\
\text { nities }\end{array}$ & $\begin{array}{l}\text { COVID-19 waste curation and } \\
\text { dumping practices }\end{array}$ & $\begin{array}{l}\text { Direction, plan, and } \\
\text { announcement related with } \\
\text { COVID-19 waste managing }\end{array}$ \\
\hline Afghanistan & $\begin{array}{l}\text { - All health-care waste produced } \\
\text { during patient care, including } \\
\text { those with confirmed } \\
\text { COVID-19 infection, is con- } \\
\text { sidered to be infectious } \\
\text { (infectious, sharps, and path- } \\
\text { ological waste) and ought to } \\
\text { be gathered securely in obvi- } \\
\text { ously stamped lined compart- } \\
\text { ments and safe boxes } \\
\text { - This waste ought to be dealt } \\
\text { with, ideally on location, and } \\
\text { afterward securely arranged } \\
\text { - Waste engendered in waiting } \\
\text { zones of health-care services }\end{array}$ & $\begin{array}{l}\text { - Isolating healthcare wastes by } \\
\text { category (such as general } \\
\text { waste, anatomical waste, and } \\
\text { other infectious waste) at the } \\
\text { point of generation } \\
\text { - Assembling sharps (used auto } \\
\text { disable syringes) separately in } \\
\text { yellow boxes. } \\
\text { - Determining storing zone at } \\
\text { healthcare services (parted } \\
\text { wastes from each ward are } \\
\text { elated by wheeled streetcars) } \\
\text { - Wastes carriage carefully and } \\
\text { packed with labeling for } \\
\text { off-site curing and dumping }\end{array}$ & $\mathrm{N} / \mathrm{F}$ & $\begin{array}{l}\text { - Preliminary Stakeholder } \\
\text { Engagement Plan (SEP), } \\
\text { March 2020; } \\
\text { - Environmental and Social } \\
\text { Commitment Plan (ESCP), } \\
\text { March 2020. }\end{array}$ \\
\hline Bangladesh & $\begin{array}{l}\text { can be classified as harmless } \\
\text { and should be inclined in } \\
\text { strong black bags and closed } \\
\text { entirely before gathering and } \\
\text { dumping by civic waste ame- } \\
\text { nities. } \\
\text { - Individuals who handle } \\
\text { medical services waste should } \\
\text { wear proper personnel } \\
\text { protective equipment/PPE } \\
\text { (boots, long-sleeved gown, }\end{array}$ & $\begin{array}{l}\text { - Utilization of isolated shading } \\
\text { coded containers (black: } \\
\text { non-dangerous waste, red: } \\
\text { sharp waste, yellow: } \\
\text { infectious/neurotic waste, and } \\
\text { so on) } \\
\text { - Storing the bins on their sites, } \\
\text { on a daily basis. } \\
\text { - Use of roofed automobiles for } \\
\text { carriage from the origin to the } \\
\text { curing sites }\end{array}$ & - Incinerator & $\begin{array}{l}\text { - National Preparedness and } \\
\text { Response Plan for COVID-19, } \\
\text { Bangladesh Version 5, } \\
\text { March } 2020 \\
\text { - Bangladesh Preparedness and } \\
\text { Response Plan for COVID-19 }\end{array}$ \\
\hline India & $\begin{array}{l}\text { heavy-duty gloves, mask, and } \\
\text { goggles or a face shield) and } \\
\text { perform hand cleanliness after } \\
\text { removing it. } \\
\text { - It is important to increase } \\
\text { capacity to handle and treat } \\
\text { this health-care waste. } \\
\text { Additional waste treatment } \\
\text { capacity, preferably through } \\
\text { alternative treatment } \\
\text { technologies, such as } \\
\text { autoclaving or high tempera- } \\
\text { ture burn incinerators, may } \\
\text { need to be procured, and sys- } \\
\text { tems may need to be put in } \\
\text { place to ensure their sustained }\end{array}$ & $\begin{array}{l}\text { - Use selective streetcars and } \\
\text { collection baskets in } \\
\text { COVID-19 isolation wards. } \\
\text { - Waste filthy with blood/body } \\
\text { fluids of COVID-19 patients } \\
\text { to be composed in yellow bag } \\
\text { for home quarantined houses. } \\
\text { - Labeling "COVID-19 Waste" } \\
\text { on the stuffs. } \\
\text { - Sterilize } \\
\text { containers/bins/trolleys with } \\
1 \% \text { sodium hypochlorite } \\
\text { solution daily on (inner and } \\
\text { outer surfaces) } \\
\text { - Allocate devoted cleanliness } \\
\text { workers distinctly for }\end{array}$ & $\begin{array}{l}\text { - Usual biomedical waste curing } \\
\text { facility (CBWTF). } \\
\text { - Dumping by deep burial where } \\
\text { CBTWF facilities are not } \\
\text { available (i.e., rural or remote } \\
\text { areas). } \\
\text { - When there is an enormous } \\
\text { volume of incinerable } \\
\text { COVID-19 waste, permit } \\
\text { HW incinerators at existing } \\
\text { treatment, stockpiling, and } \\
\text { removal offices (TSDFs) or } \\
\text { hostage modern incinerators } \\
\text { if any exist in the state/union } \\
\text { region. }\end{array}$ & $\begin{array}{l}\text { - Revision 4: Guidelines for } \\
\text { handling, treatment and } \\
\text { disposal of waste generated } \\
\text { during } \\
\text { treatment/diagnosis/quarantine } \\
\text { of COVID-19 patients, } \\
\text { July } 2020 \text {. } \\
\text { - Pictorial guide on biomedical } \\
\text { waste management rules } 2016 \\
\text { (amended in } 2018 \text { \& 2019) } \\
\text { including the CPCB guidelines } \\
\text { for handling, treatment, and } \\
\text { disposal of waste generated } \\
\text { during } \\
\text { treatment/diagnosis/quarantine } \\
\text { of COVID-19 patients. }\end{array}$ \\
\hline
\end{tabular}

biomedical waste and general solid waste gathering and transfer to provisional storage

- Use of "Biohazard" or "Cytotoxic" vehicle with GPS and barcoding frameworks for sack/compartments containing health care wastes (HCW) for squander following.

Nepal
- Designate waste storage in health facilities.

- Use of specific trollies for transportation within the hospitals.

- Use of specific vehicles for transportation from
- Habitually burned,

- Small-scale incineration, or

- Dumped backyard, municipal landfill, or other areas.
- Interim guidance for extension of COVID-19 and other health services, 2020;

- NMC Interim guidance for infection prevention and control when COVID-19 is suspected; 
Table 6 (continued)

Country WHO standard
Management of COVID-19 induced waste in healthcare amenities
COVID-19 waste curation and Direction, plan, and

dumping practices

(a)

announcement related with

COVID-19 waste managing healthcare facilities to treatment WMSPs
Sri Lanka

Pakistan

Bhutan
- Contaminated (infectious) "sharps"-collect hypodermic needles, scalpels, knives, and broken glass; always in puncture-proof containers fitted with covers and treat as infectious

- Do not recap, clip, or hypodermic needles after use

- Place complete assembly in a sharp's disposal container

- Place the disposable syringes, used alone, or with needles, in sharps disposal containers

- and incinerate them

- Do not fill the sharps container to capacity. When they are three-quarters full, place

- them in "infectious waste" containers and incinerate

- Do not discard sharps disposal containers in landfills
- All waste created from this occasion ought to be treated as irresistible waste.

- These wastes should be isolated at source, utilizing shading coding receptacles, with biohazard bag lining
- Incinerator

- Apart from sharps, autoclave all contaminated (potentially infectious) materials in leak-proof containers, e.g., autoclavable, color-coded plastic bags, before disposal

- After autoclaving, place the material in transfer containers for incineration

- Do not attempt any pre-cleaning of any contaminated (potentially infectious) materials to be autoclaved and reused

- Always perform any necessary cleaning or repair must be after autoclaving or disinfection

- If possible, do not discard materials deriving from healthcare activities in landfills even after decontamination

- Place strong (for example plastic) dispose of holders, skillet, or containers, at each work station for waste assortment

- When disinfectants are utilized, waste materials ought to stay in close contact with the disinfectant (for example not secured via air rises) for the suitable time, agreeing to the disinfectant utilized

- Infectious wastes ought to be autoclaved and delivered non-irresistible or burned
- Interim clinical guidance for care of patients with COVID-19 in health care

- Settings;

- COVID-19 Clinical management guideline; v) Guidelines for use of PPE-COVID-19;

- COVID-19 Dead body management guidelines;

- SOP for cleaning and decontamination of ambulance.

- Interim guideline for management of solid waste generated by households and places under self-quarantine due to COVID-19 outbreak.

- National action plan for preparedness and response to corona virus disease (COVID-19) Pakistan
- National preparedness and response plan for outbreak of novel coronavirus (COVID-19) 
Table 6 (continued)

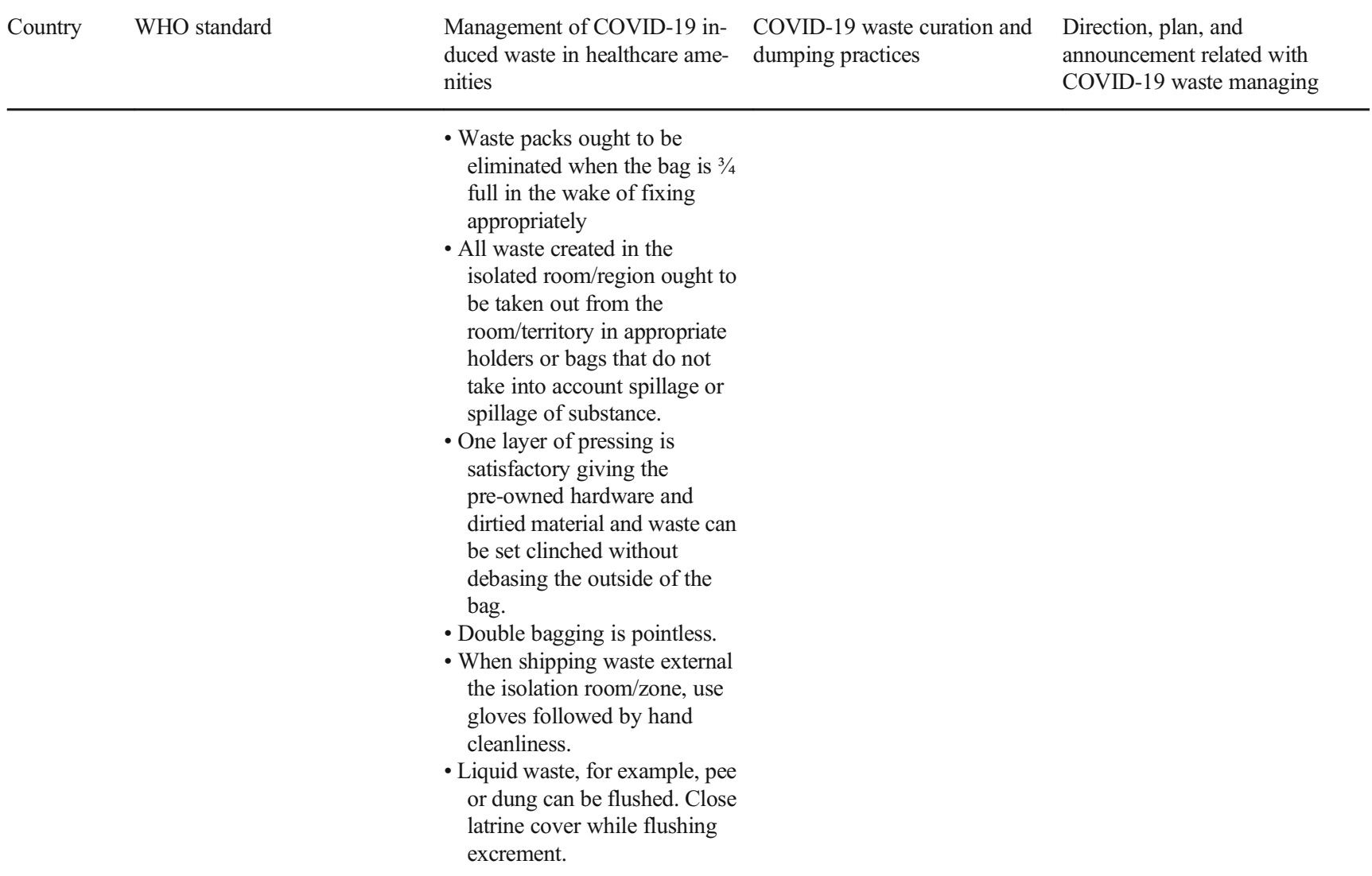

$N F$, not found; WMSP, waste management service providers; $C P C B$, Central Pollution Control Board; $N M C$, Nepal Medical Council; SOP, standard operating procedure

facility is not sufficient, hence, WHO recommended establishing burial pit for disposal of the biohazardous wastes (IGES 2020). Masks used by patients/caregivers/close contacts during home quarantine ought to be disinfected by bleach solution $(5 \%)$ or sodium hypochlorite solution (1\%) and afterward disposed either by burning or deep burial.

\section{Conclusion and recommendation}

Most people lack information on how to dispose PPE correctly. The inappropriate disposal of contaminated PPE could spread the virus throughout the population. People voiced anxiety over demolishing the spread of COVID-19 because of inappropriate removal of individual protective gears including PPE, face masks, and gloves, during the pandemic. The caution comes days after the government made it obligatory for individuals to use face masks in communities. Many people are using face masks and gloves during this period. Health professionals know how to dispose of them in the right way. However, all SA countries have related policies, plans, and guidelines on environmental cleaning, safely managed sanitation, biomedical waste disposal system, and household waste management. Unfortunately, these guidelines are not being followed due to lack of enforcement and proper monitoring. While government and non-governmental organizations have been sensitizing the public about the importance of using PPE, they do not tell us how and when to dispose them. As a result, the situation is becoming worse, even in the age of the third wave of COVID-19. In addition to governments' enforcement, it is also every citizen's responsibility to follow the relevant guidelines.

Acknowledgements The author acknowledges the Institute of Epidemiology Disease Control and Research, EcoHealth Alliance, and Chattogram Veterinary and Animal Sciences University to support the research team.

Author contribution AI has conceptualized and developed the methodology and wrote the first draft of the manuscript. MAS and MAK help AI in writing the first draft. AI, MAS, MKR, SS, SI, JF, SDC, and MMH reviewed and edited the manuscript. All authors contributed to the article and approved the submitted version. 
Funding The authors did not receive any external funds to conduct this research. However, the research team's time partially was supported by NIH U01AI153420-01 (PI Epstein) through EcoHealth Alliance.

Data availability All the data of this review are publicly available in the web.

\section{Declarations}

Ethical approval and consent to participate As this review is based on published article data so it is beyond ethical approval issues. No consent is required for this review.

Consent for publication All the authors gave their consent to publish this review.

Conflict of interest The authors declare no competing interests.

\section{References}

Abd El-Salam MM (2010) Hospital waste management in El-Beheira governorate, Egypt. J Env Manag 91:618-629

Abd Manaf L, Samah MAA, Zukki NIM (2009) Municipal solid waste management in Malaysia: practices and challenges. Waste Manag 29:2902-2906

Abdel-Shafy HI, Mansour MS (2018) Solid waste issue: sources, composition, disposal, recycling, and valorization. Egyptian J Petro 27: $1275-1290$

Abdulla F, Qdais HA, Rabi A (2008) Site investigation on medical waste management practices in northern Jordan. Waste Manag 28:450 458

ADB (2020) ADB Data Room: managing infectious medical waste during the COVID-19 pandemic. Available at: https://www.adb.org/ publications/managing-medical-waste-covid19. Accessed on 5 May 2021

Adu RO, Gyasi SF, Essumang DK, Otabil KB (2020) Medical wastesorting and management practices in five hospitals in Ghana. J Env Pub Heal 2020:1-14

Ahmed W, Angel N, Edson J, Bibby K, Bivins A, O'Brien JW, Choi PM, Kitajima M, Simpson SL, Li J (2020) First confirmed detection of SARS-CoV-2 in untreated wastewater in Australia: a proof of concept for the wastewater surveillance of COVID-19 in the community. Sci Total Environ 138764

Ahmed F, Islam MA, Kumar M, Hossain M, Bhattacharya P, Islam MT, Hossen F, Hossain MS, Islam MS, Uddin MM (2021) First detection of SARS-CoV-2 genetic material in the vicinity of COVID-19 isolation centre in Bangladesh: variation along the sewer network. Sci Total Environ 776:145724

Alam M-U, Sharior F, Ferdous S, Ahsan A, Ahmed T, Afrin A, Sarker S, Akand F, Archie RJ, Hasan K (2020) Strategies to connect lowincome communities with the proposed sewerage network of the Dhaka sanitation improvement project, Bangladesh: a qualitative assessment of the perspectives of stakeholders. Int J Environ Res Public Health 17:7201

Albastaki A, Naji M, Lootah R, Almeheiri R, Almulla H, Almarri I, Alreyami A, Aden A, Alghafri R (2020) First confirmed detection of SARS-COV-2 in untreated municipal and aircraft wastewater in Dubai, UAE: the use of wastewater based epidemiology as an early warning tool to monitor the prevalence of COVID-19. Sci Total Environ 143350

Ali M, Wang W, Chaudhry N (2016) Management of wastes from hospitals: a case study in Pakistan. Waste Manag Res 34:87-90
Ali M, Wang W, Chaudhry N, Geng Y (2017) Hospital waste management in developing countries: a mini review. Waste Manag Res 35: 581-592

Amin MA (2020) Dhaka Tribune; COVID-19: 14,500 tons waste generated, waste collector halved in a month, available at: https:/www. dhakatribune.com/bangladesh/2020/05/10/covid-19-14-500-tonswaste-generated-waste-collector-halved-in-a-month. Accessed on 22 Dec 2020

Amin N, Rahman M, Raj S, Ali S, Green J, Das S, Doza S, Mondol MH, Wang Y, Islam MA (2019) Quantitative assessment of fecal contamination in multiple environmental sample types in urban communities in Dhaka, Bangladesh using SaniPath microbial approach. PLoS ONE 14:e0221193

Amin N, Haque R, Rahman MZ, Rahman MZ, Mahmud Z, Hasan R, Sarker S, Akter N, Johnston D, Rahman M, Bhattacharya P (2021) Hospitals in Dhaka and discharge of wastewater with high SARSCoV-2 viral RNA genetic loadings: an assessment of potential environmental health risk. https:/www.researchgate.net/publication/ 351111377_Hospitals_in_Dhaka_and_discharge_of_wastewater with_high_SARS-CoV-2_viral_RNA_genetic_loadings_An assessment_of_potential_environmental_health_risk. Accessed on 25 June 252021

Ananth AP, Prashanthini V, Visvanathan C (2010) Healthcare waste management in Asia. Waste Manag 30:154-161

Aragaw TA (2020) Surgical face masks as a potential source for microplastic pollution in the COVID-19 scenario. Mar Pollut Bull 159:111517

Arora S, Nag A, Rajpal A, Tiwari SB, Sethi J, Sutaria D, Rajvanshi J, Saxena S, Shrivastava SK, Kazmi AA (2020a) Detection of SARSCoV-2 RNA in fourteen wastewater treatment systems in Uttarakhand and Rajasthan States of North India. medRxiv. https://doi.org/10.1101/2020.09.18.20197178

Arora S, Nag A, Sethi J, Rajvanshi J, Saxena S, Shrivastava SK, Gupta $\mathrm{AB},(2020 \mathrm{~b})$ Sewage surveillance for the presence of SARS-CoV-2 genome as a useful wastewater based epidemiology (WBE) tracking tool in India. medRxiv. https://doi.org/10.1101/2020.06.18. 20135277

Azharul Haq K (2006) Water management in Dhaka. Water Res Dev 22: 291-311

Babu BR, Parande A, Rajalakshmi R, Suriyakala P, Volga M (2009) Management of biomedical waste in India and other countries: a review. J Int Environ Appl Sci 4:65-78

Bahauddin K, Uddin M (2012) Prospect of solid waste situation and an approach of environmental management measure (EMM) model for sustainable solid waste management: case study of Dhaka city. J Environ Sci Nat Resour 5:99-111

Banik R, Rahman M, Sikder MT, Gozal D (2020)SARS-CoV-2 pandemic: an emerging public health concern for the poorest in Bangladesh. Pub Health Prac 100024:100024

Anon (2011) Technical Guidelines on the Environmentally Sound Coprocessing of Hazardous Wastes in Cement Kilns. Available at: http://www.basel.int. Accessed on 10 Feb 2021

Behnam B, Oishi SN, Uddin SMN, Rafa N, Nasiruddin SM, Mollah A, Hongzhi M (2020) Inadequacies in hospital waste and sewerage management in Chattogram, Bangladesh: exploring environmental and occupational health hazards. Sustainability 12:9077

Boechat CL, de Santana Arauco AM, Duda RM, de Sena AFS, de Souza MEL, Brito ACC (2017) Solid waste in agricultural soils: an approach based on environmental principles, human health, and food security. Solid Waste Manag Rural Areas 81

Casanova L, Rutala WA, Weber DJ, Sobsey MD (2009) Survival of surrogate coronaviruses in water. Water Res 43:1893-1898

Chakraborty P, Pasupuleti M, Jai Shankar MR, Bharat GK, Krishnasamy S, Dasgupta SC, Sarkar SK, Jones KC (2021) First surveillance of SARS-CoV-2 and organic tracers in community wastewater during 
post lockdown in Chennai, South India: Methods, occurrence and concurrence. Sci Total Environ 778:146252

Chartier Y (2014) Safe management of wastes from health-care activities. World Health Organization. Available at: https://apps.who.int/iris/ bitstream/handle/10665/42175/9241545259.pdf. Accessed on 10 June 2021

Cheval S, Mihai Adamescu C, Georgiadis T, Herrnegger M, Piticar A, Legates DR (2020) Observed and potential impacts of the COVID19 pandemic on the environment. Int J Environ Res Public Health $17: 4140$

Chin AWH, Chu JTS, Perera MRA, Hui KPY, Yen HL, Chan MCW, Poon LLM (2020) Stability of SARS-CoV-2 in different environmental conditions. Lancet Microbe 1:e10. https://doi.org/10.1016/ S2666-5247(20)30003-3

CNN (2020) Discarded masks and gloves are becoming a health hazard as people dump them on streets. Available at: https://edition.cnn. com/2020/04/21/us/coronavirus-ppe-masks-gloves-environmenthazard-trnd/index.html. Accessed on 10 June 2021

Dana T (2011) Hospital waste management: Bangladesh. OIDA Int J Sustain Dev 2:29-40

Datta P, Mohi GK, Chander J (2018) Biomedical waste management in India: critical appraisal. J Lab Phys 10:6-014

Dhokhikah Y, Trihadiningrum Y (2012) Solid waste management in Asian developing countries: challenges and opportunities. J Appl Environ Bio Sci 2:329-335

Dorji U, Tenzin UM, Dorji P, Wangchuk U, Tshering G, Dorji C, Shon H, Nyarko KB, Phuntsho S (2019) Wastewater management in urban Bhutan: assessing the current practices and challenges. Process Saf Environ Prot 132:82-93

Duan SM, Zhao XS, Wen RF, Huang JJ, Pi GH, Zhang SX, Research Team SARS (2003) Stability of SARS coronavirus in human specimens and environment and its sensitivity to heating and UV irradiation. Biomedical and Environmental Sciences: BES 16(3):246-255

ESDO (2020) ESDO's online press briefing on COVID-19 pandemic outbreak 14,500 tons of hazardous plastic waste in a month. Available at: https://esdo.org/esdos-online-press-briefing-onhazardous-plastic-waste-generation-in-a-month-during-covid-19pandemic. Accessed on 20 Apr 2021

Faisal GM, Hoque MN, Rahman MS, Islam T (2021)Challenges in medical waste management amid COVID-19 pandemic in a megacity Dhaka. Journal of Advanced Biotechnology and Experimental Therapeutics, 4(1).

Feng S, Shen C, Xia N, Song W, Fan M, Cowling BJ (2020) Rational use of face masks in the COVID-19 pandemic. Lancet Res Med 8:434 436

Ferdous MZ, Islam MS, Sikder MT, Mosaddek ASM, Zegarra-Valdivia J, Gozal D (2020) Knowledge, attitude, and practice regarding COVID-19 outbreak in Bangladesh: an online-based cross-sectional study. PLoS ONE 15:e0239254

Ferronato N, Torretta V (2019) Waste mismanagement in developing countries:a review of global issues. Int $\mathrm{J}$ Environ Res Public Health 16:1060

Foladori P, Cutrupi F, Segata N, Manara S, Pinto F, Malpei F, Bruni L, La Rosa G (2020)SARS-CoV-2 from faeces to wastewater treatment: what do we know? A review. Sci Total Environ 743:140444

Gerba CP, Betancourt WQ, Kitajima M (2017) How much reduction of virus is needed for recycled water: a continuous changing need for assessment? Water Res 108:25-31

Ghinai I, McPherson TD, Hunter JC, Kirking HL, Christiansen D, Joshi K, Rubin R, Morales-Estrada S, Black SR, Pacilli M (2020) First known person-to-person transmission of severe acute respiratory syndrome coronavirus 2 (SARS-CoV-2) in the USA. Lancet 395: $1137-1144$

GISAID (2021) GISAID, Available at: https://www.gisaid.org. Accessed on 21 June 2021
Goh GK-M, Dunker AK, Foster JA, Uversky VN (2020) Shell disorder analysis predicts greater resilience of the SARS-CoV-2(COVID-19) outside the body and in body fluids. Micro Path 104177:104177

Gundy PM, Gerba CP, Pepper IL (2009) Survival of coronaviruses in water and wastewater. Food Environ Viro 1:10

Gupta PK, Shree V, Hiremath L, Rajendran S (2019) The use of modern technology in smart waste management and recycling: artificial intelligence and machine learning, Recent Advances in Computational Intelligence. Springer, Champ, pp 173-188

Gwenzi W (2020) Leaving no stone unturned in light of the COVID-19 faecal-oral hypothesis? A water, sanitation and hygiene (WASH) perspective targeting low-income countries. Sci Total Environ: 141751

Haque MS, Uddin S, Sayem SM, Mohib KM (2020) Coronavirus disease 2019 (COVID-19) induced waste scenario: a short overview. J Environ Chem Engin 104660

Haque MS, Sharif S, Masnoon A, Rashid EJWM (2021a) Research, SARS-CoV-2pandemic-induced PPE and single-use plastic waste generation scenario. Waste Manag. Res. 0734242X20980828

Haque, R., Rahman, M., Amin, N., Rahman, M.Z., Mahmud, Z.H., Sarker, P., Raqib, R., Rahman, M.Z.R., Hossain, A., Johnston, D., 2021b. Inference and forecasting of SARS-CoV-2 wastewater surveillance in Bangladesh, CUGH 2021 Virtual Conference. CUGH

Haramoto E, Malla B, Thakali O, Kitajima M (2020) First environmental surveillance for the presence of SARS-CoV-2 RNA in wastewater and river water in Japan. medRxiv

Harhay MO, Halpern SD, Harhay JS, Olliaro PL (2009) Health care waste management: a neglected and growing public health problem worldwide. Trop Med Int Health 14:1414-1417

Hasan M, Iqbal SS (2016) Solid waste management of Dhaka South City Corporation (DSCC). J Environ Treat Technol 4:78-10

Hasan MK, Shahriar A, Jim KU (2019) Water pollution in Bangladesh and its impact on public health. Heliyon 5:e02145

Hassan MM, Ahmed SA, Rahman KA, Biswas TK (2008) Pattern of medical waste management: existing scenario in Dhaka City, Bangladesh. BMC Public Health 8:36

Hassan MM, El Zowalaty ME, Khan SA, Islam A, Nayem MRK, Järhult JD (2020) Role of environmental temperature on the attack rate and case fatality rate of coronavirus disease 2019 (COVID-19) Pandemic. Inf Eco Epid 10:1792620

Hemalatha M, Kiran U, Kuncha SK, Kopperi H, Gokulan CG, Mohan SV, Mishra RK (2021) Surveillance of SARS-CoV-2 spread using wastewater-based epidemiology: comprehensive study. Sci Total Environ. 768:144704

Idris A, Inanc B, Hassan MN (2004) Overview of waste disposal and landfills/dumps in Asian countries. J Mater Cycles Waste Manag 6: $104-110$

IGES (2020) Waste management during the COVID-19 pandemic from response to recovery, availabe at: https://www.unenvironment.org/ resources/report/waste-management-during-covid-19-pandemicresponse-recovery. Accessed on 27 Dec 2020

Iliyas M (2008) Disposal of Waste. Eds.: Iliyas M, Shah KS. Public Health Commu Med. 7th edition. Karachi: Time Publisher, 261-273

Ilyas S, Srivastava RR, Kim H (2020) Disinfection technology and strategies for COVID-19 hospital and bio-medical waste management. Sci Total Environ 749:141652

Islam T, Kibria MG (2020) Challenges to the prevention of COVID-19 spread in slums of Bangladesh. J Public Health. Oxford, England 40(3); 637-638

Islam A, Sayeed MA, Rahman MK, Ferdous J, Shano S, Choudhury SD, Hassan MM (2020) Spatiotemporal patterns and trends of community transmission of the pandemic COVID-19 in South Asia: Bangladesh as a case study. Bio Health 3(1):39-49

Islam A, Sayeed M, Kalam M, Ferdous J, Rahman M, Abedin J, Islam, S., Shano, S., Saha, O., Shirin, T., (2021a) Molecular epidemiology of 
SARS-CoV-2 in diverse environmental samples globally. Microorganisms 9(8):1696

Islam A, Sayeed MA, Rahman MK, Ferdous J, Islam S, Hassan M (2021b) Geospatial dynamics of COVID-19 clusters and hotspots in Bangladesh. Transbound Emerg Dis:1-15

Islam, S.M.D., Mondal, P.K., Ojong, N., Bodrud-Doza, M., 2021c. Water, sanitation, hygiene and waste disposal practices as COVID-19 response strategy: insights from Bangladesh. J Env Dev Sustain, 1-22

Jui UM (2020) A worrying spike in hazardous plastic waste during the pandemic, available at: https://tbsnews.net/panorama/worryingspike-hazardous-plastic-waste-during-pandemic-82606. Accessed on 1 Feb 2021

Kam K-q, Yung CF, Cui L, Tzer Pin Lin R, Mak TM, Maiwald M, Li J, Chong CY, Nadua K, Tan NWH (2020) A well infant with coronavirus disease 2019 with high viral load. Clinical Inf Dis.

Kamal A, Goyer K, Koottatep T, Amin A (2008) Domestic wastewater management in South and Southeast Asia: the potential benefits of a decentralised approach. Urban Water J 5:345-354

Kataki S, Chatterjee S, Vairale MG, Sharma S, Dwivedi SK (2020) Concerns and strategies for wastewater treatment during COVID19 pandemic to stop plausible transmission. Res Con Recy 105156: 105156

Kerdsuwan S, Laohalidanond K (2015) Efficiency improvement for medical waste management. Handbook of Clean Energy Systems:1-11

Khan AA, Ahmed Z, Siddiqui MA (2012) Issues with solid waste management in South Asian countries: a situational analysis of Pakistan. J Environ Occup Health 1:129-131

Kitajima M, Ahmed W, Bibby K, Carducci A, Gerba CP, Hamilton KA, Haramoto E, Rose JB (2020)SARS-CoV-2 in wastewater: state of the knowledge and research needs. Sci Total Environ 139076: 139076

Kojima M, Iwasaki F, Johannes HP, Edita EP (2020) Strengthening waste management policies to mitigate the COVID-19 pandemic

Kumar S, Smith SR, Fowler G, Velis C, Kumar SJ, Arya S, Rena K, Cheeseman RC (2017) Challenges and opportunities associated with waste management in India. Royal Soc Open Sci 4:160764

Kumar M, Patel AK, Shah AV, Raval J, Rajpara N, Joshi M, Joshi CG (2020a) First proof of the capability of wastewater surveillance for COVID-19 in India through detection of genetic material of SARSCoV-2. Sci Total Environ 746:141326

Kumar M, Patel AK, Shah AV, Raval J, Rajpara N, Joshi M, Joshi C.G.J.S.o.T.T.E., (2020d) First proof of the capability of wastewater surveillance for COVID-19 in India through detection of genetic material of SARS-CoV-2. 746, 141326

LeChevallier MW, Mansfield TJ, Gibson JM (2020) Protecting wastewater workers from disease risks: personal protective equipment guidelines. Wat Env Res 92:524-533

Lesimple A, Jasim SY, Johnson DJ, Hilal N (2020) The role of wastewater treatment plants as tools for SARS-CoV-2 early detection and removal. J Wat Pro Eng, 101544.

Lo IL, Lio CF, Cheong HH, Lei CI, Cheong TH, Zhong X, Tian Y, Sin NN (2020) Evaluation of SARS-CoV-2 RNA shedding in clinical specimens and clinical characteristics of 10 patients with COVID-19 in Macau. Int J Bio Sci 16:1698-1707

Mahmood S, ud Din N, Mohsin J, Javed H (2011) Practices regarding hospital waste management at public and private sector hospitals of Lahore. Annals of King Edward Med Univ 17:113-113

Mandal P, Gupta AK, Dubey BK (2020) A review on presence, survival, disinfection/removal methods of coronavirus in wastewater and progress of wastewater-based epidemiology. J Environ Chem Eng: 104317

Mansour G, Islam W, Akhtaruzzaman M (2017) Situation analysis of the urban sanitation sector in Bangladesh. Available at: https://www. aguaconsult.co.uk/wp-content/uploads/Situation-analysis-of-the-
urban-sanitation-sector-in-Bangladesh.pdf. Accessed on 10 May 2021

Medema G, Heijnen L, Elsinga G, Italiaander R, Brouwer A (2020) Presence of SARS-coronavirus-2 RNA in sewage and correlation with reported COVID-19 prevalence in the early stage of the epidemic in the Netherlands. Environ Sci Technol Lett 7(7):511-516

Mohankumar S, Kottaiveeran K (2011) Hospital waste management and environmental problems in India. Int J Pharma Bio Arch 2(6):16211626

Mohee R (2005) Medical wastes characterisation in healthcare institutions in Mauritius. Waste Manag 25:575-581

MOHFW (2008) The medical waste management rules, 2008; availabe at: http://www.clcbd.org/document/133.html. Accessed 23 Dec 2020

Napit R, Manandhar P, Chaudhary A, Shrestha, B., Poudel, A., Raut, R., Pradhan, S., Raut, S., Mathema, S., Rajbhandari R (2021) Rapid genomic surveillance of SARS-CoV-2 in a dense urban community using environmental (sewage) samples. medRxiv. https://doi.org/ $10.1101 / 2021.03 .29 .21254053$

Nasrin F (2016) Waste management in Bangladesh: current situation and suggestions for action. Int Res J Soc Sci 5:36-42

Nghiem LD, Morgan B, Donner E, Short MD (2020) The COVID-19 pandemic: considerations for the waste and wastewater services sector. Case Studies Chem Environ Eng 100006:100006

Nzediegwu C, Chang SX (2020) Improper solid waste management increases potential for COVID-19 spread in developing countries. Res Con Recy 161:104947

Ouhsine O, Ouigmane A, Layati E, Aba B, Isaifan R, Berkani M (2020) Impact of COVID-19 on the qualitative and quantitative aspect of household solid waste. Global J Environ Sci Manage 6:41-52

Pandey D, Verma S, Verma P, Mahanty B, Dutta K, Daverey A, Arunachalam K (2020)SARS-CoV-2 in wastewater: challenges for developing countries. Int J Hygiene Environ Health 113634:113634

Peccia J, Zulli A, Brackney DE, Grubaugh, N.D., Kaplan, E.H., Casanovas-Massana, A., Ko, A.I., Malik, A.A., Wang, D., Wang, M.J.m (2020) SARS-CoV-2 RNA concentrations in primary municipal sewage sludge as a leading indicator of COVID-19 outbreak dynamics. medRxiv. https://doi.org/10.1101/2020.05.19.20105999

Penteado CSG, de Castro MAS (2020)Covid-19 effects on municipal solid waste management: what can effectively be done in the Brazilian scenario? Res Con Recy 164:105152

Qu G, Li X, Hu L, Jiang G (2020) An imperative need for research on the role of environmental factors in transmission of novel coronavirus (COVID-19). ACS Publications

Quilliam RS, Weidmann M, Moresco V, Purshouse H, O'Hara Z, Oliver DM (2020) COVID-19: the environmental implications of shedding SARS-CoV-2 in human faeces. Environ Int 140:105790

Rabenau HF, Cinatl J, Morgenstern B, Bauer G, Preiser W, Doerr HW (2005) Stability and inactivation of SARS coronavirus. Med Microbiol Immunol 194(1-2):1-6. https://doi.org/10.1007/s00430004-0219-0

Ragaert P, Verbeke W, Devlieghere F, Debevere, J.J.F.q., preference (2004) Consumer perception and choice of minimally processed vegetables and packaged fruits 15:259-270

Rahman MH, Akter R, Behl T, Chowdhur, MA, Mohammed M, Bulbul IJ, Elshenawy SE, Kamal M.AJCPD (2020a)COVID-19 outbreak and emerging management through pharmaceutical therapeutic strategy 26:5224-5240

Rahman MM, Bodrud-Doza M, Griffiths MD, Mamun MA (2020b) Biomedical waste amid COVID-19: perspectives from Bangladesh. Lancet, Global Health

Randazzo W, Truchado P, Cuevas-Ferrand E, Simón, P., Allende, A., Sánchez, G (2020a)SARS-CoV-2 RNA in wastewater anticipated COVID-19 occurrence in a low prevalence area. Water Res, 115942. 
Randazzo W, Truchado P, Cuevas-Ferrando E, Simón P, Allende A, Sánchez GJ (2020b)SARS-CoV-2 RNA in wastewater anticipated COVID-19 occurrence in a low prevalence area. Wat Res 181: 115942

Ray A (2008) Waste management in developing Asia: can trade and cooperation help? J Environ Dev 17:3-25

Rimoldi SG, Stefani, F., Gigantiello, A., Polesello, S., Comandatore, F., Mileto, D., Maresca, M., Longobardi, C., Mancon, A., Romeri, F.J.S.o.t.T.E (2020) Presence and infectivity of SARS-CoV-2 virus in wastewaters and rivers 744:140911

Rume, T., Islam, S.D.-U., 2020. Environmental effects of COVID-19 pandemic and potential strategies of sustainability. Heliyon, e04965.

Saadat S, Rawtani D, Hussain CM (2020) Environmental perspective of COVID-19. Sci Total Environ 138870:138870

Sangkham S (2020) Face mask and medical waste disposal during the novel COVID-19 pandemic in Asia. Case Studies Chem Environ Eng 100052:100052

Sembiring E, Nitivattananon V (2010) Sustainable solid waste management toward an inclusive society: integration of the informal sector. Res, Con Recy 54:802-809

Shammi M, Tareq SM (2020) Environmental catastrophe of COVID-19: disposal and management of PPE in Bangladesh. Global Soc Wel 8: $1-4$

Shammi M, Behal A, Tareq SM (2020) The escalating biomedical waste management to control the environmental transmission of COVID19 pandemic: a perspective from two South Asian countries. Env Sci Tech 55(7):4087-4093

Sharif S, Ikram A, Khurshid A., Salman, M., Mehmood, N., Arshad, Y., Ahmad, J., Angez, M., Alam, M.M., Rehman L 2020. Detection of SARS-coronavirus- 2 in wastewater, using the existing environmental surveillance network: an epidemiological gateway to an early warning for COVID-19 in communities. medRxiv. https://doi.org/ 10.1101/2020.06.03.20121426

Sharma HB, Vanapalli KR, Cheela VS, Ranjan VP, Jaglan AK, Dubey B, Goel S, Bhattacharya J (2020) Challenges, opportunities, and innovations for effective solid waste management during and post COVID-19 pandemic. Res, Con Recy 162:105052

Sharma S, Batra S, Gupta S, Sharma VK, Rahman MH, Kamal MA (2021) Persons with co-existing neurological disorders: risk analysis, considerations and management in COVID-19 pandemic. CNS Neuro Dis Drug Targets. https://doi.org/10.2174/ 1871527320666210308113457

Sharmin, A., 2016. Water and wastewater in Bangladesh, current status and a design of a decentralized solution

Sheheli S (2007) Waste disposal and management system in rural areas of mymensingh. Progr Agri 18:241-246

Shekdar AV (2009) Sustainable solid waste management: an integrated approach for Asian countries. Waste Manag 29:1438-1448

Sinclair RG, Choi CY, Riley MR, Gerba CP (2008) Pathogen surveillance through monitoring of sewer systems. Adv Appl Micro 65:249

Singh N, Tang Y, Ogunseitan OA (2020a) Environmentally sustainable management of used personal protective equipment. Environ Sci Tech 54:8500-8502

Singh N, Tang Y, Zhang Z, Zheng C (2020b)COVID-19 waste management: effective and successful measures in Wuhan, China. Res Con Recy 163:105071

Sizun J, Yu MW, Talbot PJ (2000) Survival of human coronaviruses 229E and OC43 in suspension and after drying onsurfaces: a possible source ofhospital-acquired infections. J Hosp Infect 46:55-60

Somani M, Srivastava AN, Gummadivalli SK, Sharma A (2020) Indirect implications of COVID-19 towards sustainable environment: an investigation in Indian context. Biores Tech Rep 11:100491

Sunkari ED, Korboe HM, Abu M, Kizildeniz T (2020) Sources and routes of SARS-CoV-2 transmission in water systems in Africa: are there any sustainable remedies? Sci Total Environ 142298: 142298
Syed EH, Mutahara M, Rahman M (2012) Medical waste management (MWM) in Dhaka, Bangladesh: it'sa review. Home Health Care Manag Pract 24:140-145

Tajmim T (2020) Dengue threat rises amid Covid-19. Available at: https://tbsnews.net/bangladesh/health/dengue-threat-rises-amidcovid-19-111973. Accessed on 1 Feb 2021

Thakur V, Ramesh A (2015) Healthcare waste management research: a structured analysis and review (2005-2014). Waste Manag Res 33: 855-870

Thompson RC, Moore CJ, Vom Saal FS, Swan SH (2009) Plastics, the environment and human health: current consensus and future trends. Philos Trans R Soc B Biol Sci 364:2153-2166

Trivedi M, Mathur M, Johri P, Singh A, Tiwari RK (2020) Waste management: a paradigm shift, environmental concerns and sustainable development. Springer, pp 337-363

Tudor T, Noonan C, Jenkin L (2005) Healthcare waste management: a case study from the National Health Service in Cornwall, United Kingdom. Waste Manag 25:606-615

Unicef (2020) Water, sanitation and hygiene. Available at: https://www. unicef.org/bangladesh/en. Accessed on 22 Dec 2020

Van Doremalen N, Bushmaker T, Morris DH, Holbrook MG, Gamble A, Williamson BN, Tamin A, Harcourt JL, Thornburg NJ, Gerber SI (2020) Aerosol and surface stability of SARS-CoV-2 as compared with SARS-CoV-1. New England J Med 382:1564-1567

Wang XW, Li JS, Jin M, Zhen B, Kong QX, Song N, Xiao WJ, Yin J, Wei W, Wang GJ, Si BY, Guo BZ, Liu C, Ou GR, Wang MN, Fang TY, Chao FH, Li JW (2005) Study on the resistance of severe acute respiratory syndrome-associated coronavirus. J Virol Methods 126: $171-177$

Warnes SL, Little ZR, Keevil CW (2015) Human coronavirus 229E remains infectious on common touch surface materials. MBio 6(6): e01697-ee1715. https://doi.org/10.1128/mBio.01697-15

WaterAid (2019) Faecal Sludge Management Landscape in South Asia. Available at: https://washmatters.wateraid.org. Accessed on 10 June 2021

WHO (2005a) Management of solid health-care waste at primary healthcare centres: a decision-making guide. Available at: https://www. who.int. Accessed on 2 Apr 2021

WHO (2005b) Management of solid health-care waste at primary healthcare centres: a decision-making guide, Availabe at: https://www. who.int/water sanitation health/medicalwaste/en/ guidancemanual1.pdf. Accessed on 22 Dec 2020. WHO Document Production Services, Geneva, Switzerland

WHO (2018)Health-care waste. Available at: https://www.who.int/newsroom/fact-sheets/detail/health-care-waste. Accessed on 28 Jan 2021

WHO (2020) Joint monitoring programme (JMP), WHO, UNICEF. Available at: https://washdata.org/data. Accessed on 22 Dec 2020

Wölfel R, Corman VM, Guggemos W, Seilmaier M, Zange S, Müller MA, Niemeyer D, Jones TC, Vollmar P, Rothe C (2020) Virological assessment of hospitalized patients with COVID-2019. Nature 581: 465-469

Wong G, Bi Y-H, Wang Q-H, Chen X-W, Zhang Z-G, Yao Y-G(2020) Zoonotic origins of human coronavirus 2019 (HCoV-19/SARSCoV-2): why is this work important? Zool Res 41:213-219

Worldometer (2021) Coronavirus, Available at: https://www. worldometers.info/coronavirus. Accessed 25 June 2021

Wu F, Xiao A, Zhang J, Moniz K, Endo N, Armas F., Bonneau, R., Brown MA, Bushman, M., Chai P (2020a)SARS-CoV-2 titers in wastewater foreshadow dynamics and clinical presentation of new COVID-19 cases. medRxiv. https://doi.org/10.1101/2020.06.15. 20117747

Wu Y, Guo C, Tang L, Hong Z, Zhou J, Dong X, Yin H, Xiao Q, Tang Y, Qu X (2020b) Prolonged presence of SARS-CoV-2 viral RNA in faecal samples. Lancet Gastro Hepa 5:434-435

Wurtzer, S., Marechal, V., Mouchel, J., Maday, Y., Teyssou, R., Richard, E., Almayrac, J., Moulin, L.J.E., 2020. Evaluation of lockdown 
effect on SARS-CoV-2 dynamics through viral genome quantification in waste water, Greater Paris, France, 5 March to 23 April 2020. 25, 2000776.

Xiao F, Tang M, Zheng X, Liu Y, Li X, Shan H (2020) Evidence for gastrointestinal infection of SARS-CoV-2. Gastroenterology 158: $1831-1833$

Xu S, Li Y (2020) Beware of the second wave of COVID-19. The Lancet 395:1321-1322

Xu B, Kraemer MU, Gutierrez B, Mekaru S, Sewalk K, Loskill A, Wang L, Cohn E, Hill S, Zarebski A (2020a) Open access epidemiological data from the COVID-19 outbreak. Lancet Infect Dis 20:534

Xu Y, Li X, Zhu B, Liang H, Fang C, Gong Y, Guo Q, Sun X, Zhao D, Shen J (2020b) Characteristics of pediatric SARS-CoV-2 infection and potential evidence for persistent fecal viral shedding. Nat Med 26:502-505

Yaqub T, Nawaz, M., Shabbir, M.Z., Ali, M.A., Altaf, I., Raza, S., Shabbir, M.A.B., Ashraf, M.A., Aziz, S.Z., Cheema SQ (2020) A longitudinal survey for genome-based identification of SARS-CoV2 in sewage water in selected lockdown areas of Lahore city, Pakistan; a potential approach for future smart lockdown strategy. medRxiv. https://doi.org/10.1101/2020.07.31.20165126
Yasmin S, Rahman MI (2017) A review of solid waste management practice in Dhaka City, Bangladesh. Int Journal Environ Prot Pol 5:19-25

Yu H, Sun X, Solvang WD, Zhao X (2020) Reverse logistics network design for effective management of medical waste in epidemic outbreaks: insights from the coronavirus disease 2019 (COVID-19) outbreak in Wuhan (China). International Journal of Environmental Research and Public Health 17:1770

Zamparas M, Kapsalis V, Kyriakopoulos G, Aravossis K, Kanteraki A, Vantarakis A, Kalavrouziotis I (2019) Medical waste management and environmental assessment in the Rio University Hospital, Western Greece. Sustain Chem Pharm 13:100163

Zhang D, Ling H, Huang X, Li J, Li W, Yi C, Zhang T, Jiang Y, He Y, Deng S (2020) Potential spreading risks and disinfection challenges of medical wastewater by the presence of severe acute respiratory syndrome coronavirus 2 (SARS-CoV-2) viral RNA in septic tanks of Fangcang hospital. Sci Total Environ 741:140445

Publisher's note Springer Nature remains neutral with regard to jurisdictional claims in published maps and institutional affiliations. 